\title{
Capital Formation in Monetary Growth Models: An Empirical Study of Selected Arab Countries
}

\author{
Osamah Bin Tareef*, Walid Shawaqfeh \\ Business Economics Department, Faculty of Business, University of Jordan, Amman, Jordan \\ Email address: \\ osa2011@gmail.com (O. B. Tareef),w.shawaqfeh@ju.edu.jo (W. Shawaqfeh) \\ ${ }^{*}$ Corresponding author
}

To cite this article:

Osamah Bin Tareef, Walid Shawaqfeh. Capital Formation in Monetary Growth Models: An Empirical Study of Selected Arab Countries. International Journal of Business and Economics Research. Vol. 8, No. 2, 2019, pp. 50-57. doi: 10.11648/j.ijber.20190802.12

Received: February 11, 2019; Accepted: April 10, 2019; Published: April 29, 2019

\begin{abstract}
The purpose of this paper is to investigate factors affecting capital formation in selected Arab Countries. These countries are Bahrain, Egypt, Jordan, Kuwait, Morocco, and Saudi Arabia. It adopts neoclassical monetary growth models derived from Sidrauski model to examine the substitution relationship between money and capital. Further analysis has been conducted to examine the complementarity relationship between money and capitalthat was driven based on Mackinnon argument. In his argument Mackinnon objected the perfect substitution relationship between capital and money in developing countries, where financial markets are immature and inefficient. Accordingly, investors will depend on self financing, where savings are held in money. As a result, an increase in money demand will contribute in increasing capital. Moreover, Mackinnon emphasizes the role of government expenditure in improving capital stock. The analysis has been performed with unbalanced pooled data, and models have been tested by using the GLS method considering fixed and random effects. The results indicate that self-financing and government expenditure play a significant role in improving capital stock. These results are consistent with Mackinnon argument and might explain the contribution of money supply in improving capital stock in developing countries.
\end{abstract}

Keywords: Growth Model, Capital Formation, Inflation Rate, Interest Rate, Money Supply

\section{Introduction}

Capital is one of the main factors of production that is required to attain nation's development. It contributes to outputs increase, employment improvement, income level enhancement, and poverty reduction. Accumulating capital is defined as an addition to the fixed assets of the economy plus net changes in the level of inventories. Fixed assets include land improvement, plant, machinery, equipment purchase, road construction, railways, schools, offices, hospitals, private residential dwellings, and commercial and industrial buildings (World Bank). Accordingly, capital accumulation is an addition to society's wealth and might explain the basic differences between developed and developing countries.

The problem of capital formation deals with three aspects: savings, financing, and investment. However, early theories of capital have connected the process of accumulating capital to fluctuations in interest rates and short-term investments. Neoclassical economists provided numerous models that formulate the contribution of different factors in accumulating capital. The basic one has been introduced by Solow and Swan (1956), in which growth of capital is influenced by savings level, growth of labor force, and technology. Their assumption that savings are held in a form of fixed assets ignores alternative choices like liquid assets, money, or bonds. These alternatives were presented by Tobin (1965) and Sidrauskis (1967). They argued that individuals hold their wealth in a diversified portfolio, consisting of money, liquid assets, and fixed assets. Therefore, money and fixed assets are perfect substitutes. On the other hand, Mackinnon (1973) discussed the main differences between developing and developed countries in terms of the form at which savings are held. In his argument, Mackinnon presented a complementarity relationship between money and fixed assets in developing countries, where money holding will contribute to capital stock improvement. [29]

Like other developing economies, Arab countries still face several challenges in achieving sustainable growth. These 
challenges arise from the fact that most of these countries have low level of income. In addition, they are vulnerable to fluctuation in global prices as they rely on exporting raw materials and importing manufactured goods. In consequence, most of the Arab countries suffer from shortage and/or high fluctuation in national savings, which has negatively affectedthe ability to financenew investment and development projects. Accordingly, they were unable to accumulate the intended level of capital. In response, Arab countries conduct fiscal and monetary policies to overcome these challenges. They conduct the monetary policy by central banks through adopting a set of instruments. The main objective of such policy is stabilizing inflation rates. On the other hand, fiscal policy is adopted to achieve growth and reduce income inequality. Indeed, most of the economic theories indicate that integrating these policies ensures growth. Accordingly, this study tries to investigate factors influencing capital formation in Arab countries based on neoclassical monetary growth models through investigating the effect of monetary variables on capital formation, taking into account the role played by government expenditure.

The paper is organized as follows: the following section presents the theoretical framework; the third section reviews the previous empirical literature. Section four presents the model and data used in the analysis, while section five discusses economic conditions in the Arab countries. Model estimation and empirical results are illustrated in the sixth section, and the seventh section presents the conclusion.

\section{Theoretical Framework}

Solow and Swan (1956) presented a pioneer growth model to explore the differences between countries in terms of development. Their model discusses the growth path of capital based on the following assumptions: (1) production function with constant return to scale that satisfies Inada conditions, and (2) Labor, capital and knowledge are the only factors of production. They argued that the growth path of capital can be expressed by [9]:

$$
\Delta k_{t}=s f\left(k_{t}\right)-(n+g+\delta) k_{t}
$$

where: $\Delta k_{t}$ represents changes in capital, $s$ : saving rate, $f\left(k_{t}\right)$ : production function, $n$ : growth in labor force, $g$ : improvement in technology, and $\delta$ : depreciation rate.

Since Solow and Swan model does not consider the effect of monetary variables, Tobin (1965) questioned the motives of savings when the expected rate of return earned on fixed assets is unattractive. He postulates that communities with low rates of returns will not save unless there are alternative assets that act as a store of value other than capital. Accordingly, individuals hold their wealth in a diversified portfolio that consisted of fixed and monetary assets. Based on such an argument, Tobin presented a simple growth model under the assumption that money is the only monetary form of wealth that yields a certain rate of return. As a result, the growth of capital is influenced by individuals' behavior under portfolio propositions in which savings are channeled to either real balances or capital.

Sidrauski (1967) presented a microeconomic model depending on maximizing the utility of a representative family as a function of consumption and money holdings. This model considers real wealth, the real value of government transfer and expected inflation, but in order to analyze the whole economy, he presented a macro model that considers stock of capital, population and nominal quantity of money and the growth rate of these variables [21]. Based on this analysis, Sidrauskis concluded that under certain assumptions that govern the flow of services of holding money; the capital stock is independent of changes in money in long run, while in short run; an expansionary monetary policy will increase consumption and reduce capital formation. However, the growth path of capital can be expressed by equation 2 , which is driven from the income constraint presented by Sidrauski in money in utility model (MIU) [7].

$$
\Delta k_{t}=s\left[f\left(\frac{k_{t}}{n}\right)+\tau_{t}+\frac{(1-\delta)}{1+n} K_{t}+\frac{\left(1+i_{t-1}\right) B_{t}+M_{t}}{\left(1+\pi_{t+1}\right)(n)}\right]-\left[\Delta \frac{M_{t}}{P_{t}}\right]-\left[\Delta \frac{B_{t}}{P_{t}}\right]
$$

where: $\Delta \mathrm{k}_{\mathrm{t}}$ represents changes in capital, s: saving rate, $\mathrm{f}\left(\frac{\mathrm{k}_{\mathrm{t}}}{\mathrm{n}}\right)$ : production function, $\mathrm{n}$ : labor force, $\delta$ : depreciation, $\tau_{\mathrm{t}}$ : government transfer, $\mathrm{i}_{\mathrm{t}-1}$ : coupon rate, $\mathrm{B}_{\mathrm{t}}$ : bonds holding, $\mathrm{M}_{\mathrm{t}}$ : broad money supply, and $\mathrm{P}_{\mathrm{t}}$ : price level.

In his book "Money and Capital in Economic Development", Mackinnon (1973) criticized these models on the base that they do not consider the nature of financial structure found in developing countries. In these countries, financial markets are immature and inefficient, which will limit investors'abilities to finance their investmentsfrom financial intermediaries. Accordingly, they will depend on self-financing, where savings are held in the form of money and used to finance investment activities. Therefore, complementarity relationship is established between capital and money, where the increase in money holding will contribute in accumulating capital. Consequently, an increase in real return will increase money demand, which can be expressed by the following function [29]:

$$
\left(\frac{M}{P}\right)^{D}=f\left(Y, \frac{I}{Y}, i-\pi\right)
$$

where: $\mathrm{Y}$ is income, $\frac{I}{Y}$ : is the investment income ratio, and $i-\pi$ : is the real return.

The second part of Mackinnon's argument is related to the source of capital financing. He criticized neoclassical models on the base that they consider savings as the only source for financing capital, ignoring the role of the public sector. This role is expected to be significantin contributing and stimulating capital formation, especially in developing countries, where government intervention exceeds taxes and subsidies to massive investment. Accordingly, public expenditure could contribute topublic wealth increase, if it is directed suitably. 


\section{Empirical Review}

Capital is considered as one of the major sources of economic growth. Its importance arises from the strong positive relationship with the output. This relationship is approved by the work of Thirlwall (1974), Robinson (1971), Puriand Misra(2006) [3, 34, 37]. Yet, Levine and Renelt(1992)reported that the direction of this relationship is ambiguous [27]. Blomstrom, Lipsey and Zejan (1993) have addressed the question of causality between investment and income growth. They found no evidence that fixed investment is the key to income growth since income induces capital formation more than capital formation induces growth [18]. In developing countries, Sunny and Osuagwu (2016) found a positive relationship between capital and economic growth in Nigeria [14]. While Song and others (2013) found that economic growth promotes fixed asset investment in China [39]. However, Makdisi, Fattah, and Limam (2000) found that capital in the MENA region is characterized by high volatility and less efficiency compared to other regions [33].

The effect of money on real economic factors is subject of considerable debate among economists. Friedman and Schwartz (1963)analyzed the sources of movements in money stock in The United States from the end of the Civil War to 1960 . Their findings show that causality relationship goes from money to output [6]. Andersen and Jordan (1968) presented their equation which depends on the regression of output on money. They concluded that monetary actions have a significant impact on nominal income [16], but their results do not provide powerful evidence in supporting the effect of money over real income fluctuations. Their model was criticized on the basis of the direction of the relationship and the goals of the monetary policy, where stabilizing actions have limited effect or have no effect on income. However, Olanipekun and Akeju (2013), Hassan (2015) and Ihugba (2015) examined the relationship between money supply and capital based on neoclassical models. Their findings support the existence of a positive relationship between these variables $[8,22,23]$. The robustness of this relationship was examined through general equilibrium model that is found in the work of Cole, Mailath, and Pstlewaite (1995), Aruoba, Waller and Wright (2005), and Schreft and Smith (1997) [12, 31, 35]. Furthermore, McCandless and Weber (1995) examined the effect of monetary interventions on inflation rates. They found a strong correlation between these two variables [11]. Lucas (1996) differentiates between anticipated monetary growth, which will affect the inflation and interest rate, without affecting employment or production, and unanticipated money growth which can stimulate production [28].

The role of saving in developed countries was examined by Ogaki, Ostryand Reinhart (1996). They found that saving in these countries is not stimulated by the increase in real interest rate due to consumer preferences [20]. Azar, Bolbol, and Mouradian (2018) found that private saving in Arab countries is related to long-run GDP growth. However, savings contribute to development when it is directed toward investment [32]. The effect of the saving-investment gap in developing countries was examined by Adom and Elbahnasawy (2014) and Gocer, Akin and Alatas (2016). As expected, findings support the negative effect of such a gap on economic development $[1,13]$.

The relationship between capital and interest rate has been examined repeatedly in developing countries. Khumalo (2014) examined the relationship between capital formation (inform of investment) and real interest in South Africa. He found a negative relationship between these variables [15]. In Jordan, Bader and Malawi (2010) reported that an increase in interest rate will affect negatively capital formation [17]. Wuhan, Suyuan, and Khurshid (2015), who examined the relationship between interest rate and capital in China, found a negative relationship between these two variables in the long run and a positive one in the short run [38].

King and Levine (1993) examined the contribution of financial intermediaries on capital formation by introducing a model on the base of theoretical growth models. Their results show that financial intermediaries benefit growth through assessing new projects, mobilizing saving and diversifying risks [26]. Creane and others (2004) reported that the MENA region has witnessed improvement in financial sector development indices, yet there are differences across countries [30]. Haddad and Hakim (2015) examined the role of banking system in six Arab countries pre and post Arabic spring. They found that banking sector is neutral to economic development [19]. In contrast, Osman (2014) found a positive long-run relation between private credit and economic growth in Saudi Arabia [10]. Ojimadu, Aniebo and Ogu (2016) and Omankhanlen (2012) reported a positive relationship between private credit and capital formation in Nigeria $[25,2]$.

Economists presented contradictory opinions about the direction of the relationship between inflation rates and capital formation. Dasilva-Filho (2007) and Ahortor and Adenutsi (2009) showed that an increase in inflation uncertainty is associated with substantial reductions in investing in fixed assets [36, 5]. However, Onwe and Olarenwaju (2014) found a positive long-run relationship between inflation rate and corporate investment; yet, the relation is negative in the short run [24].

\section{Economic Conditions in the Arab Countries}

All Arab countries have suffered from political instability conditions either internally or externally as well as wars and armed struggles. These cruel conditions contributed to restrictions in development efforts and infrastructure destruction. Accordingly, all these countries are classified as developing countries, although some of them are considered as high-income countries. In comparison with other regions, figure 1 shows that Arab region (ARB) has the lowest level of capital formation compared to North America (NAC), 
Euro area (EMU), Latin America \& Caribbean countries (LCN). This position has been maintained along the period between 2000 and 2016. On the other hand, all of the Arab countries lie behind emerging countries that were able to achieve superior growth in capital formation like South Korea, Mexico, and Turkey; their levels of capital formation in 2016 were 330, 256, and 215 billion USD, respectively, whereas, the highest level of capital formation between Arab countries was in Saudi Arabia that equals 185 billion USD. ${ }^{1}$

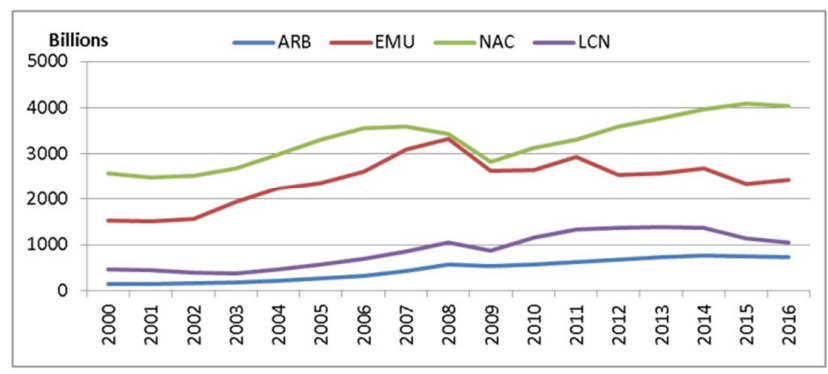

Figure 1. Capital formation Around the World based on Group Level.

Arab economies are vulnerable to fluctuation in global prices because they depend on exporting raw materials and importing manufactured goods. In response, they adopted a monetary policy that focuses on controlling inflation rates and maintaining exchange rates. During the early years of executing monetary policy, Arab Central Banks adopted direct intervention instruments. In these days, the Central bank of Bahrain (CBB) conducts monetary policy by adopting a set of instruments that help in controlling exchange rates and money supply. However, the CBB does not impose any limits on the market interest rate. Egypt, Jordan and Saudi Arabia adopted interest rate corridor, in which central banks decide periodically the ceiling and the floor of interest rates in the market. In addition, they control the money supply by controlling the required reserve. In Morocco, Bank Al-Maghrib (BAM) conducts the monetary policy through adopting two instruments: the interest rate applied to BAM's seven-day advances and the required reserve. However, before the financial crises, the economic conditions in Arab countries had improved forced by the increase in oil prices, which increased inflation rates. The period followed the financial crises in 2008, most Arab countries adopted an expansionary monetary policy by reducing interest rates. In 2016, the increase in budget deficit and decline in oil prices created a significant decline in liquidity.

The public sector plays a significant role in economic activities in the Arab countries, even though its role declined during the last few decades. During the first half of the 1980s, government expenditure contributed to more than $50 \%$ in GDP in most of the Arab countries. This contribution declined to $30 \%$ after the year 2000. In Saudi Arabia, authorities adopt a counter cycle fiscal policy with high saving in prosperity periods and high spending in periods of contraction. On average, government expenditure in Saudi Arabia represents $23.8 \%$ of GDP. The same average is also found in Jordan and Kuwait. In Egypt, average government expenditure constitutes 13\% of GDP. While in Morocco and Bahrain the averageconstitutes $18 \%$ of GDP. However, the following section will discuss the data and methodology. It presents major differences between Arab countries in terms of examined variables.

\section{Data and Methodology}

This study examines the determinants of capital formation in six Arab countries. Data is gathered from various databases including The World Bank, The International Monetary Fund (IMF) and central banks. The analysis was performed using unbalanced panel data techniques due to differences in data series between countries. However, countries were chosen based on the availability of data, where countries and examined periods are depicted in Table 1.

Table 1. Countries and Periods Examined.

\begin{tabular}{lllllll}
\hline Countries & Bahrain & Egypt & Jordan & Kuwait & Morocco & $\begin{array}{l}\text { Saudi } \\
\text { Arabia }\end{array}$ \\
\hline \multirow{2}{*}{ Periods } & $1981-$ & $1977-$ & $1977-$ & $1981-$ & $1979-$ & $1997-$ \\
& 2015 & 2016 & 2016 & 2016 & 2016 & 2016 \\
\hline
\end{tabular}

The relationships between capital formation and explanatory variables were examined by presenting two econometrics' models. The first model is derived based on money in utility (MIU) model (Sidrauski, 1967), under the assumption that individuals in Arab countries hold their wealth inform of either money or fixed assets. The second model is presented based on Mackinnon argument, which was discussed earlier (Mackinnon, 1973). These models can be expressed by the following equations:

$$
\begin{gathered}
1^{\text {st }} \text { model } \Delta k=\beta_{0}+\beta_{1} m+\beta_{2} s+\beta_{3} \pi+\beta_{4} n+\beta_{5} i+\varepsilon \mathrm{p} \\
2^{\text {nd }} \text { model } \Delta k=\beta_{0}+\beta_{1} m+\beta_{2} s+\beta_{3} \pi+\beta_{4} G o v+\beta_{5} C r+\varepsilon
\end{gathered}
$$

where: $\Delta k$ represents growth rate in gross capital formation. $m$ : Growth rate in broad money supply. $s$ : Growth rate in gross domestic savings. $\pi$ : Inflation rate defined by GDP deflator. $n$ : Growth rate in total population. $i$ : First difference in Real interest rate. Gov: Growth rate in general government final consumption expenditure. $\mathrm{Cr}$ : Growth rate in domestic credit provided by financial sector.

\section{Empirical Analysis}

Table 2 depicts the descriptive statistics that provide some information about the data set for the grouped countries. Further information is presented in Annex I, which illustrate the major differences between countries. The tables show that the mean value of the growth in capital formation for the examined countries is $8.7 \%$, which is considered very high compared to the mean growth for the World $(3.14 \%)^{2}$. 
Bahrain (11\%) and Saudi Arabia (10\%) were able to achieve growth rates in capital that exceed the group growth rate. The mean growth rate in broad money supply is $9.7 \%$, which is very close to the mean growth rates in Bahrain, Egypt, Jordan, and Saudi Arabia. For Morocco and Kuwait, the mean growth in money is $8.8 \%$ and $7.4 \%$ respectively. In Jordan and Kuwait, the mean growth rate of saving is negative that indicatesthe dissaving behavior in both countries, where excess consumption is financed either from loans or saving carried from previous periods. On the other hand, the mean value of inflation in Egypt is $11 \%$, which is considered very high compared to the mean value in other countries, where the second highest value is in Jordan with a value $5.7 \%$.

Table 2. Summary of descriptive statistic (1978-2016).

\begin{tabular}{|c|c|c|c|c|c|c|c|c|}
\hline & $\Delta \boldsymbol{k}$ & Gov & $\mathrm{Cr}$ & $\boldsymbol{m}$ & $n$ & $s$ & $i$ & $\pi$ \\
\hline Mean & 0.087 & 0.071 & 0.251 & 0.097 & 0.030 & 0.130 & 0.152 & 5.31 \\
\hline Median & 0.062 & 0.065 & 0.102 & 0.085 & 0.026 & 0.056 & 0.098 & 4.98 \\
\hline Maximum & 1.87 & 0.463 & 40.8 & 0.936 & 0.080 & 25.0 & 15.0 & 41.9 \\
\hline Minimum & -0.604 & -0.332 & -12.6 & -0.418 & -0.03 & -10.2 & -11.8 & -27.0 \\
\hline Std. Dev. & 0.23 & 0.10 & 3.06 & 0.119 & 0.02 & 1.97 & 3.41 & 8.94 \\
\hline Skewness & 2.42 & 0.04 & 10.94 & 1.53 & 0.65 & 8.93 & 0.17 & -0.10 \\
\hline Kurtosis & 19.91 & 5.21 & 150.6 & 15.5 & 3.81 & 125.8 & 6.3 & 5.95 \\
\hline Jarque-Bera & (2705) & 43 & (192996) & (1445) & 20.52 & (134940) & 85.3 & 76.6 \\
\hline Observations & 210 & 210 & 208 & 208 & 206 & 210 & 187 & 210 \\
\hline
\end{tabular}

In order to achieve the objectives, this paper will investigate the determinants of capital formation based on monetary growth models through testing the introduced models thatexpressed by equations 1 and 2 . The intended variables are examined in terms of stationarity using Levin, Lin and Chu text. The results are summarized in table 3, where all variables are found stationary at level, (i.e. I(0)). Moreover, the independent variables in each model have been examined for multicollinearityby estimating the correlation coefficients between these variables. Tables 4 and 5 depict a weak relationship between the dependent variables in each module.

Table 3. Unit Root Test.

\begin{tabular}{|c|c|c|c|c|c|c|c|}
\hline \multicolumn{7}{|c|}{ Levin, Lin \& Chu t* } & \multirow{3}{*}{ Result } \\
\hline \multirow{2}{*}{ Variable } & \multicolumn{2}{|c|}{ Individual intercept } & \multicolumn{2}{|c|}{ Individual intercept \& trend } & \multicolumn{2}{|l|}{ None } & \\
\hline & Statistic & Prob. & Statistic & Prob. & Statistic & Prob. & \\
\hline$\Delta k$ & -5.37 & 0.00 & -4.84 & 0.00 & -7.19 & 0.00 & $\mathrm{I}(0)$ \\
\hline$m$ & -4.02 & 0.00 & -2.92 & 0.00 & -5.43 & 0.00 & $\mathrm{I}(0)$ \\
\hline$n$ & -5.86 & 0.00 & -8.15 & 0.00 & -3.04 & 0.00 & $\mathrm{I}(0)$ \\
\hline Gov & -4.33 & 0.00 & -3.44 & 0.00 & -4.3 & 0.00 & $\mathrm{I}(0)$ \\
\hline $\mathrm{Cr}$ & -5.67 & 0.00 & -4.27 & 0.00 & -6.8 & 0.00 & $\mathrm{I}(0)$ \\
\hline$S$ & -11.3 & 0.00 & -9.65 & 0.00 & -12.3 & 0.00 & $\mathrm{I}(0)$ \\
\hline$\pi$ & -3.24 & 0.00 & -1.80 & 0.03 & -5.33 & 0.00 & $\mathrm{I}(0)$ \\
\hline$i$ & -6.39 & 0.00 & -5.20 & 0.00 & -10.6 & 0.00 & $\mathrm{I}(0)$ \\
\hline
\end{tabular}

Table 4. Correlation Coefficients between variables in the first model.

\begin{tabular}{lllllll}
\hline & \multicolumn{1}{c}{$\boldsymbol{i}$} & & $\boldsymbol{\pi}$ & $\boldsymbol{m}$ & $\boldsymbol{n}$ & $\boldsymbol{s}$ \\
\hline$i$ & 1 & & & & & \\
$\pi$ & -0.097 & 1 & & & & \\
$m$ & 0.066 & 0.129 & 1 & & \\
$n$ & 0.047 & -0.013 & 0.028 & 1 & 1 \\
$s$ & -0.103 & 0.070 & 0.015 & -0.012 & 1 \\
\hline
\end{tabular}

Table 5. Correlation coefficients between variables in the second model.

\begin{tabular}{cllllll}
\hline \multicolumn{1}{r}{$\boldsymbol{\pi}$} & \multicolumn{1}{c}{$\boldsymbol{m}$} & \multicolumn{1}{c}{$\boldsymbol{s}$} & $\boldsymbol{C r}$ & $\boldsymbol{G o v}$ \\
\hline$\Pi$ & 1 & & & & \\
$m$ & 0.148 & 1 & & & \\
S & 0.057 & 0.007 & 1 & & \\
Cr & 0.049 & -0.003 & 0.014 & 1 & \\
Gov & 0.188 & 0.402 & -0.039 & 0.103 & 1 \\
\hline
\end{tabular}

Based on the nature of the data, the analysis is performed depending on unbalanced pooled data. In dealing with such data set, the fixed / random effect has been examined in order to address the error term behavior. This test is performed using Housman test. The results in table 6 showthat random effect model is the appropriate one in estimating both of the intended models. However, the considered models have been estimated using generalized least square as a simple weighted least squares (GLS-WLS) in order to overcome the unbalanced panel data econometrics' problems. The ordinary least squares estimation (OLS) might be the best linear unbiased estimator when variance component equals zero, but in case of positive variance, residuals are biased [4]. Table 7 shows estimation results of the considered models using the (GLS-WLS) method.

Table 6. Hausman Test results.

\begin{tabular}{lll}
\hline Null hypotheses and the random effect model is the appropriate model & $\mathbf{1}^{\text {st }}$ Model & 2nd model \\
\hline Correlated Random Effects - Hausman Test & 2.17 & 2.861 \\
Prob. & {$[0.82]$} & {$[0.72]$} \\
\hline
\end{tabular}

The estimated result of model 1 indicates the existence of strong and significant impact of growth rate of broad money 
supply, growth rate of saving and inflation rate on the growth rate of capital formation. The estimated coefficient of growth of money supply equals 0.57 . This indicates that an increase in the growth rate of broad money supply by one unit will induce growth rate of capital formation by 0.57 of a unit. The positive sign of the coefficient indicates that the increase in broad money has a positive effect on capital formation, which complies with (Olanipekun and others 2013) study, who found a positive and significant relationship between growth of capital and growth of money supply in Nigeria [8]. Hassan (2015) and Ihugba (2015) also reported the same positive relationship between these two variables [22, 23]. These results are also consistent with the complementarity relationship between capital formation and broad money supply, as discussed by Mackinnon.

A positive relationship between growth of saving rate and growth of capital formation is found, where, the estimated coefficient equals 0.019 . Thisindicates that an increase in the growth rate of saving by one unit will induce growth rate of capital by 0.019 units. Furthermore, inflation rates have a positive effect on capital formation with estimated coefficient equals 0.004 . On the other hand, the effect of interest rate on capital formation is found to be negative, while growth of population is found to be positive. Even though these two results are found insignificant, they are consistent with economic theory.

The estimation result of model 2 indicates that all explanatory variables have a significant impact on dependent variable, with the exception of growth in credit provided to the private sector. This result supports the self-financing argument presented by Mackinnon, which can be found in the work of Ojimadu, Aniebo and Ogu, (2016), who found a positive insignificant relationship between capital formation and banks credit in Nigeria [25]. Moreover, the estimated coefficient of growth of money supply maintains its positive sign, yet it has declined to 0.51 compared to its value in model 1. Growth in government expenditure is significant in affecting capital formation at $10 \%$ level of confidence. This gives signs of the importance of government role in improving growth rate of capital formation in Arab countries, which is consistent with Mackinnon argument. Finally, growth rate in saving and inflation rate maintains their positiveimpact and signs as in model 1.

Table 7. Estimating results.

\begin{tabular}{cll}
\hline \multicolumn{2}{l}{ Dependent Variable: $\Delta \boldsymbol{k}$} & \\
\hline Variable & Model 1 & Model 2 \\
\hline$m$ & $* 0.574[4.29]$ & $* 0.516[3.97]$ \\
$s$ & $* 0.019[3.17]$ & $* 0.019155[3.52]$ \\
$\pi$ & $* 0.004[2.41]$ & $* 0.003[2.18]$ \\
$i$ & $-0.004[-0.958]$ & \\
$n$ & $0.799[0.853]$ & $* * 0.280[1.836039]$ \\
Gov & & $-0.007[-1.53]$ \\
Cr & & 0.183 \\
R-squared & 0.169 & $9.06[0.00]$ \\
F-statistic & $7.27[0.00]$ & \\
\hline * Significant at 5\% & & \\
** Significant at $10 \%$ & &
\end{tabular}

\section{Conclusion}

According to the previous econometric results, this study indicates the positive effect of money supply on capital formation, which implies that money is not neutral in Arab countries. Furthermore, results came consistent with the argument presented by Mackinnon (1973), where a positive significant relationship between money supply and capital formation in the selected Arab countries proves the complementarity relationship between these two variables. Moreover, the positive and significant relationship found between saving and capital formation, and the insignificant negative relationship between credit provided to the private sector and capital formation support investors self-financing argument that is presented by Mackinnon. These results reflect the immaturity of financial intermediaries and require adopting a set of procedures to improve financial intermediaries' efficiency and their contribution to productive economic activities. On the other hand, the relationship between inflation rates and capital formation is found positive and significant, which support the preferences of owning fixed assets in case of increased inflation rates. Finally, Government expenditure has a positive impact on capital formation, which is found significant at $10 \%$ level of significant. This highlights the importance of government role in Arabic countries.

\section{Appendix}

Table 8. Descriptive statistics for each country.

\begin{tabular}{|c|c|c|c|c|c|c|c|c|c|}
\hline Country & Statistic & $\pi$ & $i$ & $\mathrm{Cr}$ & Gov & $\Delta \boldsymbol{k}$ & $m$ & $\boldsymbol{n}$ & $\boldsymbol{s}$ \\
\hline \multirow{9}{*}{ Bahrain } & Mean & 2.89 & 6.07 & -0.31 & 0.08 & 0.12 & 0.10 & 0.04 & 0.09 \\
\hline & Median & 2.61 & 7.44 & 0.12 & 0.06 & 0.06 & 0.07 & 0.03 & 0.06 \\
\hline & Maximum & 16.65 & 15.55 & 2.40 & 0.25 & 1.87 & 0.94 & 0.08 & 1.49 \\
\hline & Std. Dev. & 8.24 & 5.36 & 2.39 & 0.07 & 0.43 & 0.19 & 0.02 & 0.31 \\
\hline & Skewness & -0.80 & -0.48 & -4.20 & 1.11 & 2.04 & 1.91 & 0.92 & 2.55 \\
\hline & Kurtosis & 3.97 & 3.23 & 21.86 & 3.58 & 9.61 & 12.07 & 2.80 & 13.71 \\
\hline & Jarque-Bera & 5.12 & 1.32 & 621.67 & 7.68 & 88.02 & 141.35 & 5.00 & 205.45 \\
\hline & Probability & 0.08 & 0.52 & 0.00 & 0.02 & 0.00 & 0.00 & 0.08 & 0.00 \\
\hline & Observations & 35 & 33 & 35 & 35 & 35 & 35 & 35 & 35 \\
\hline \multirow{3}{*}{ Egypt } & Mean & 11.08 & 0.05 & 0.11 & 0.07 & 0.08 & 0.11 & 0.02 & 0.07 \\
\hline & Median & 10.02 & 0.28 & 0.12 & 0.08 & 0.09 & 0.11 & 0.02 & 0.06 \\
\hline & Maximum & 37.19 & 12.17 & 0.36 & 0.27 & 0.35 & 0.47 & 0.03 & 0.34 \\
\hline
\end{tabular}




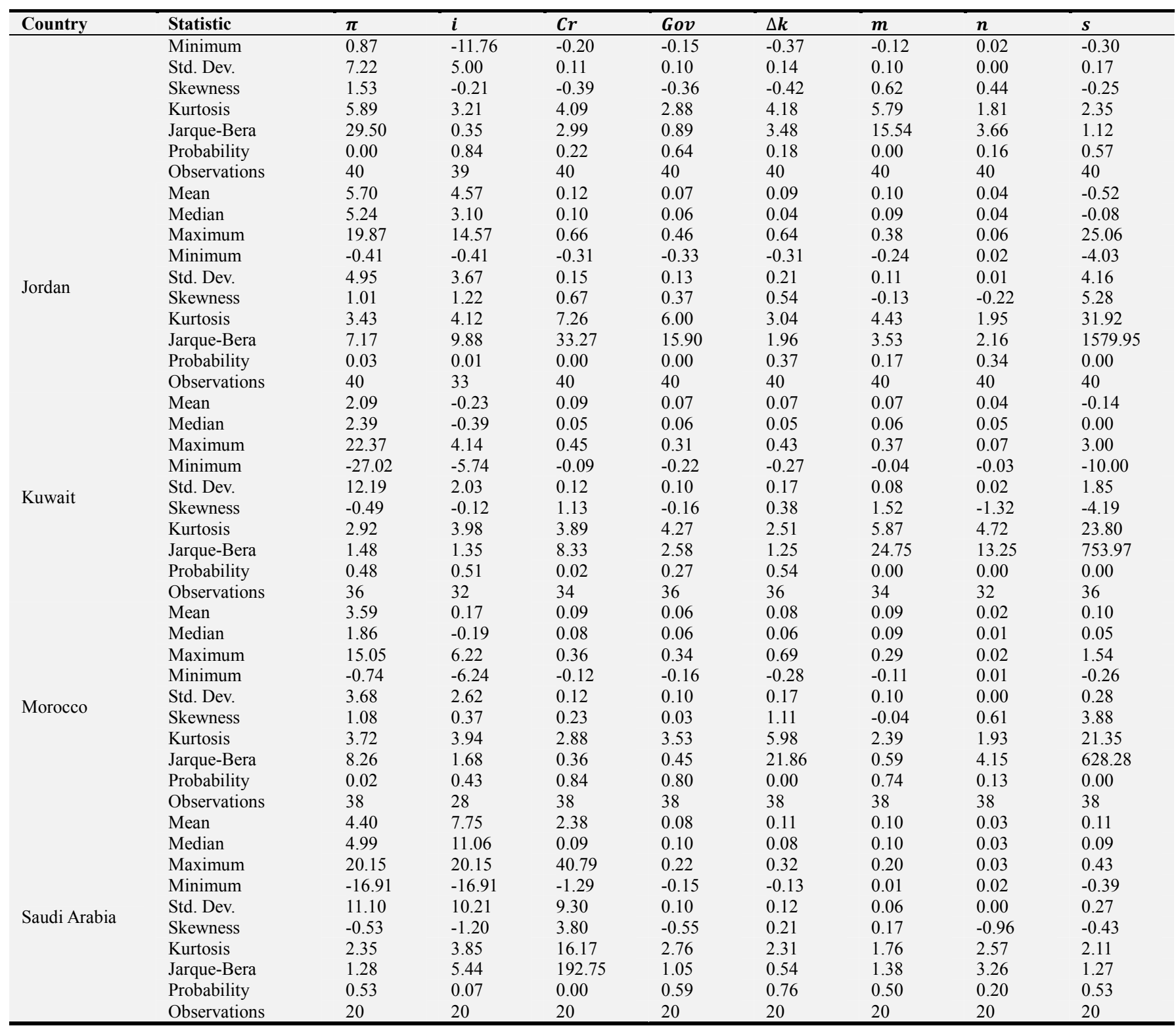

No. 29353. URL: https://mpra.ub.unimuenchen.de/29353/1/MPRA_paper_29353.pdf, 2009.

\section{References}

[1] A. Adom, and N. Elbahnasawy, "Saving-Investment Gap and Economic Growth in Developing Countries: Simulated Evidence from Selected Countries in Africa," British Journal of Economics Management and Trade, 4(10): 1585-1598, 2014.

[2] A. Omankhanlen, "The Role of Banks in Capital Formation and Economic Growth: The Case of Nigeria". Economy Transdisciplinarity Cognition. Vol. 15, Issue 1/2012 103-111, 2012.

[3] A. Thirlwall, "Inflation, Savings and Growth in Developing Economics," Macmillan, London. 1974.

[4] B. Baltagi, "Econometric Analysis of Panel Data," $3^{\text {rd }}$ ed. John Wiley and sons Ltd., 2005.

[5] C. Ahortor and D. Adenutsi, "Inflation, capital accumulation and economic growth in import-dependent developing countries," Munich Personal RePEc Archive. MPRA Paper

[6] C. Romer and D. Romer, "Friedman and Schwartz's Monetary Explanation of the Great Depression: Old Challenges and New Evidence," https://www.aeaweb.org/conference/2013/retrieve.php?pdfid= $465,2013$.

[7] C. Walsh, "Monetary theory and policy" 3rd edition. Massachusetts Institute of Technology, 2010.

[8] D. Olanipekun and K. Akeju, "Money Supply, Inflation and Capital Accumulation in Nigeria," Journal of Economics and Sustainable Development ISSN 2222-1700 (Paper) ISSN 2222-2855 (Online) Vol. 4, No. 4, 2013.

[9] D. Romer, "Advanced Macroeconomics," 4th Edition, University of California, Berkeley. 2012.

[10] E. Osman, "The Impact of Private Sector Credit on Saudi Arabia Economic Growth (GDP): An Econometrics Model Using (ARDL) Approach to Cointegration," American International Journal of Social Science. Vol. 3, No. 6, 2014. 
[11] G. McCandless and W. Weber, "Some Monetary Facts," Federal Reserve Bank of Minneapolis vol19-no. 3 ISSN 02715287,1995

[12] H. Cole, G. Mailath, and A. Pstlewaite, "Incorporating concerns for relative wealth in economic models," Research Gate CARESS. WP \#95-14, 1995.

[13] I. Gocer, T. Akin, and S. Alatas, "The effects of savinginvestment gap on economic growth in developing countries: A clustering and panel data analysis," Theoretical and Applied Economics, Volume XXIII. No. 2(607), pp. 157-172, 2016.

[14] I. Sunny and N. Osuagwu, "Impact of Capital Formation on the Economic Development of Nigeria," Fifth International Conference on Global Business, Economics, Finance and Social Sciences (GB16Chennai Conference) ISBN: 978-1943579-74-7 Chennai-India. 1-3 April, 2016. Paper ID: CF610, 2016.

[15] J. Khumalo, "Interest Rate - Private Capital Formation Nexus in South Africa: Bounds Test Approach," Mediterranean Journal of Social Sciences, MCSER Publishing, Rome-Italy, E-ISSN 2039-2117, ISSN 2039-9340, 2014.

[16] L. Anderson and J. Jordan, "Monetary and Fiscal Actions: A Test of Their Relative Importance in Economic Stabilization," URL:

https://files.stlouisfed.org/files/htdocs/publications/review/68/ 11/Monetary_Nov1968.pdf, 1968.

[17] M. Bader and A. Malawi, "The Impact of Interest Rate on Investment in Jordan: A Cointegration Analysis," JKAU: Econ. \& Adm. Vol. 24 No. 1, pp: 199-209 (2010 A.D./1431 A.H.) DOI: 10.4197/Eco. 24-1.6, 2010.

[18] M. Blomstrom, R. Lipsey and M. Zejan, "Is Fixed Investment the Key to Economic Growth?," NBER. WP No. 4436, 1993.

[19] M. Haddad, and S. Hakim, "Can Banks Lead The Economic Recovery Of The Arab Spring?," The Economic Research Forum (ERF). WP 965. https://erf.org.eg/wpcontent/uploads/2015/12/965.pdf., 2015.

[20] M. Ogaki, J. Ostry, and C. Reinhart, "Saving Behavior in Low and Middle-Income Developing Countries: A Comparison," IMF Staff Papers 43(1):38-71, URL: http://www.jstor.org/stable/3867352, 1996.

[21] M. Sidrauskis, "Rational choice and pattern of Growth in Monetary Economy," The American Economic Review volume 57, issue 2, 1967.

[22] O. Hassan, "The Impact of Monetary Policy on Private Capital Formation in Nigeria," Journal of Empirical Economics. Vol. 4 NO3, 138-153, 2015.

[23] O. Ihugba, "Effect of Nigeria Expansionary Monetary Policy on Investment Growth," The IIER International Conference, Berlin, Germany, 26th August 2015, ISBN: 978-93-85465-76$5,2015$.

[24] O. Onwe and R. Olarenwaju, "Impact of Inflation on Corporate Investment in the Sub-Saharan African Countries: An Empirical Analysis of the West-African Monetary Zone,"
International Journal of Business and Social Science. Vol. 5. No. 8(1), 2014.

[25] P. Ojimadu, C. Aniebo, and C. Ogu, "Bank Credit and Capital Formation in Nigeria," Journal of Policy and Development Studies. Vol. 10, No. 2. ISSN: 157-9385, 2016.

[26] R. King and R. Levine, "Finance, entrepreneurship, and growth," Journal of Monetary Economics 32 (1993) 513-542. North-Holland, 1993.

[27] R. Levine and D. Renelt, "A Sensitive Analysis of cross country growth regression," American Economic Review Vol. 82 Issue (Sep., 1992), 942-963, 1992.

[28] R. Lucas, "Two Illustrations of the Quantity Theory of Money," URL: https://www.bu.edu/econ/files//01/Lucas2illustrations1.pdf, 2011.

[29] R. Mckinnon, "Money and Capital," $1^{\text {st }}$ Edition. The Brooking Institution, 1973.

[30] S. Creane, R. Goyal, A. Mobarak, and R. Sab, "Financial Sector Development in the Middle East and North Africa," International Monetary Fund. WP/04/201, 2004.

[31] S. Aruoba, C. Waller and R. Wright, "Money and Capita," Federal Reserve Bank of New York. URL: https://www.newyorkfed.org/medialibrary/media/research/con ference /2005/monetary-policy/aruoba.pdf, 2005.

[32] S. Azar, A. Bolbol and A. Mouradian, "Private Savings in the Arab Countries: Empirical Analysis and Policy Implications," International Journal of Economics and Finance. Vol. 10, No. 7, ISSN 1916-971X, 2018.

[33] S. Makdisi, Z. Fattah and I. Limam, "Determinants of Growth in the MENA Countries," World Bank sponsored Workshop on the Global Development Network held in Prague during the period June 9-11, 2000.

[34] S. Robinson, "Sources of Growth in Less Developed Countries: A Cross-Section Study," Quarterly Journal of Economics Volume 85, issue 3, 339-408, 1971.

[35] S. Schreft and B. Smith, "Money, banking, and capital formation," Journal of Economic Theory vol. 73, Mar1997. pp 157-82, 1997.

[36] T. Dasilva-Filho, "Are Core Inflation Directional Forecasts Informative?," Banco Central do Brasil, WB, No 266, 2012.

[37] V. Puri and Misra S, "Economics of development and planning," Himalaya publishing house, 16th revised edition, 2016.

[38] Wuhan, Suyuan and A. Khurshid, “ The effect of interest rate on investment; Empirical evidence of Jiangsu Province, China,"Journal of International StudiesVol. 8, No 1, 2015, pp. 81-90. DOI: 10.14254/2071-, 2015.

[39] Y. Song, Y. Jiang, G. Song, and P. Wang, "The Empirical Research on the Relationship between Fixed Assets Investment and Economic Growth," Research and Applications in Economics. Vol. 1 Iss. 1, 2013. 